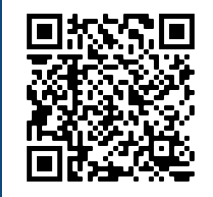

Keywords:

Wood orientation

Thermal treatment

Dilatometry

Mechanical strength

Historic:

Received 21/01/2020

Accepted 30/04/2020

+Correspondence: luisra24@gmail.com
Raúl Espinoza-Herrera', Luis Olmos ${ }^{2+}$, Isaac Alfaro Trujillo', Pedro Garnica-Gonzalez ${ }^{3}$

\section{STUDY OF THERMAL EXPANSION AND COMPRESSION STRENGTH OF THREE WOOD SPECIES FROM PLANTATIONS}

ESPINOZA-HERRERA, R.; OLMOS, L.; TRUJILLO, I.A.; GARNICA-GONZALEZ, P. Study of thermal expansion and compression strength of three wood species from plantations. CERNE, v. 26, n. 2, p.256-264, 2020.

\section{HIGHLIGHTS}

Dimensional changes during thermal treatment were evaluated by dilatometry.

Anisotropy in the thermal expansion of woods was assessed.

Thermal treatment increased the mechanical strength of studied woods.

The lowest density woods showed a higher mass loss due to heat treatment.

\section{ABSTRACT}

The objective of this study was to evaluate the effect generated by a thermal treatment on the dimensional changes and compression behavior of three wood species from commercial plantations (Eucalyptus nitens, Tectona grandis and Gmelina arborea). To accomplish the goal, dilatometric and compression tests were performed in the three directions of wood. It was found a high anisotropy of the coefficient of linear thermal expansion (CTE) as well as of the compression strength of the woods. Higher values of CTE in the tangential direction than in the radial direction were measured, meanwhile in the longitudinal direction were null. In terms of mechanical strength, the longitudinal direction showed the highest strength. The radial strength was slightly higher than the tangential one. Thermal treatment increased the strength to compression and the resistance to deformation in the elastic region. The modulus of elasticity increased up to $30.9 \%$, the stress at proportional limit up to $27.3 \%$ and the modulus of rupture up to $30.3 \%$, in the longitudinal direction. The thermal treatment had a higher effect on the mechanical properties of the lowest density wood. On the contrary, the mass loss increased for these species, finding values around twice than those obtained for the denser wood. 


\section{INTRODUCTION}

The demand of wood is increasing worldwide and it cannot always be obtained from natural forests. Commercial forest plantations (CFP) have been established to overcome this problem. Currently, in Mexico there are CFP of introduced species such as Eucalyptus nitens, Gmelina arborea and Tectona grandis, among others. Due to its fast-growing, adaptability to different environments and low-temperature resistance, E. nitens, an Australian native species, is widely used for paper manufacturing and wood-based boards fabrication. In addition, the E. nitens wood has been gradually considered as an alternative for the furniture and construction industries G. arborea is native from Asia and it is widely employed worldwide due to its fastgrowing and diversity of uses. In Mexico, this species easily adapts to both the humid and the dry tropics. The G. arborea wood has a slow drying rate and is prone to drying deformations and development of cracks, because it has a large proportion of juvenile wood and to its fast-growing (Moya and Leandro, 20I0). G. arborea heartwood is durable; nevertheless, sapwood is considered non-durable and very susceptible to attack by rot fungi and xylophagous insects (Gonzáles and Serrano, 2012). T. grandis is the most widely planted tropical wood, with $74 \%$ of the total hardwoods plantations in the world (Keogh, 2009). It also has been recognized as a high quality timber attributable to its excellent properties, becoming a very valuable wood (Bhat et al., 200I). Although, commercial forest plantations would help to solve the wood for paper and boards shortage, they produce a highly unstable material caused by the fast-growing of trees and their high proportion of juvenile wood, which may cause severe problems during their processing as lumber (Ananías et al., 2014). The aforesaid is caused by the inferior properties of wood produced by commercial forest plantations compared to that of natural forests, which may limit the use of the first. Therefore, it is important to study these woods in order to have a better understanding of their behavior as primal matter.

The thermal treatment is used to reduce wood hygroscopicity and to increase its decay resistance, which is accomplished primarily by partial thermal degradation of hemicellulose. This treatment is considered environmentally friendly since it does not require any toxic chemicals (Pelaez et al., 20I3). Thermal treatment normally consists in heating up the wood from 120 to $280^{\circ} \mathrm{C}$, for periods ranging from a few minutes to several hours. This procedure can be implemented in humid environments, using hot water or steam, or in dry environments, using nitrogen or air (Pelaez et al., 2013). The temperatures and intervals of time aplied in this process differ according to the species, the wood dimensions, moisture content (MC) and potential use of the wood (Esteves et al., 20I4; Kesik et al., 20l4). The thermal treatment can cause a reduction in the mechanical strength of the timber (Calonego et al., 2012). Temperatures below $140^{\circ} \mathrm{C}$ result in less change in physical properties, and heating above $300^{\circ} \mathrm{C}$ leads to severe wood degradation. The thermal treated wood usually presents darkening, a tendency to crack and split (lbach, 2010) as well as a mass loss, which depends on the temperature, the exposure time and the size of the samples (Gunduz and Aydemir, 2009). Several authors have found significant reduction in mechanical strength from $190-200^{\circ} \mathrm{C}$ or when periods are long lasting. The thermal treatment of Eucalyptus camaldulensis at $180^{\circ} \mathrm{C}$ for ten hours caused a decrease in the compressive strength of 19.0\%, (Unsal and Ayrilmis, 2005). Fagus sylvatica and Picea abies woods that were thermally modified at $200^{\circ} \mathrm{C}$ presented losses in the moduli of both rupture and elasticity at static bending of 40 and $20 \%$, 44 and 4\%, respectively (Kamdem et al., 2002; Bekhta and Niemz, 2003). Eucalyptus globulus wood thermally modified at 190 and $210^{\circ} \mathrm{C}$ presented decreases in the moduli of both rupture and elasticity at static bending of 50 and $15 \%$, respectively (Esteves et al., 2007). Eucalyptus grandis samples thermally modified at 200 and $220^{\circ} \mathrm{C}$ showed a decrease in modulus of elaticity at compression parallel to grain of 3.9 and $5.5 \%$, respectively. And a reduction in compressive strength parallel to grain of $5.6 \%$ (Calonego et al., 20I2).

The wood shows unique physical and mechanical behaviors as a function of moisture and temperature (Miki et al., 2014). The wood expands caused by an increase in temperature. However, the wood thermal expansion has been considered during the years as a minor problem compared to its hygroscopic deformations (Goli et al., 2019). That is because when wood is heated, its shrinkage by moisture loss is more significant than its thermal expansion (Goli et al., 2019). Therefore, the research on the wood thermal expansion is rather lacking in literature. Nevertheless, separating thermal and hygroscopic effects could give important information about the behavior of wood and a better understanding of the role of temperature in the deformation of a wooden object (Goli et al., 2019).

In the building industry, considerable attention needs to be paid to deformation, otherwise cracks, 
undesired strain and movement will lead to serious damage to the structure of buildings. To avoid these problems, it is necessary to understand the value of the expansion or contraction of building materials. The coefficient of thermal expansion (CTE) is a measure of the relative change of dimension caused by a change in temperature (Glass and Zelinka, 2010). The CTE is recognised as a fundamental parameter in mechanical and structural design applications of materials (Zeisig et al., 2002). Thermal change of wood is an important factor in the wood drying process since temperature variations cause water to flow in the wood, and consequently hygroscopic deformations occur (Goli et al., 2019; Kaung and Thanate, 2020). For example, musical instruments are very sensitive objects, where even minimal deformations can damage its varnishes (Goli et al., 2019).

Comparing CTE values as critical parameters for evaluating the bond between two materials is a common practice. (Pizzo et al., 2002) using the CTE, evaluated the interfacial compatibility bond between wood and epoxy resins. The CTE of wood depends on species, moisture content (MC), specific gravity, temperature levels and anatomical directions (Miki et al., 20l4). The CTEs of wood rise with higher MCs than those in dry condition; they have a linear relation with density (Goli et al., 2019, Kaung and Thanate, 2020). Thermal expansion of wood is mostly positive in all directions. Nevertheless, wood has different CTE values in its radial, tangential and longitudinal directions (Kaung and Thanate, 2020). The CTE value in longitudinal direction is very small, ranging from 5-10 times less than that of transverse direction, and therefore, it is not often considered (Glass and Zelinka, 2010), while that in the radial direction is slightly less than that in the tangential direction (Zhao et al., 2016). In addition, dilatometry is a technique that estimate the thermal expansion of different materials in order to obtain the coefficients of linear thermal expansion at different temperatures (Okaji, 1988; Evans, 1999); consequently, the thermal expansion value for different woods has been studied with this technique (Kubler et al., I973; Zeriouh and Belkbir, 1996; Pizzo et al., 2002; Miki et al., 20l4; Zhao et al., 20l6).

The ability of wood to withstand a load depends on several factors, including the type, direction and duration of loading, the presence or absence of defects (knots and splits), the MC and temperature (Kaung and Thanate, 2020).

The resistance to longitudinal compression of wood is important when designing elements subjected to axial loads such as columns, piles and posts. The resistance to lateral compression of the wood is related to the lateral hardness and resistance to perpendicular shearing of the fibers (Robles and Echenique, 1983). Therefore, the compression tests are one of the best indicators to estimate the mechanical strength of wood. Consequently, in this work the compressive strength and the thermal expansion of the three woods coming from commercial forest plantations were evaluated before and after a thermal treatment. Because the wood has anisotropic nature, its anatomical, physical and mechanical characteristics vary according to the direction in which they are measured; the resistance to compression and dimensional changes were evaluated in each direction of wood. Besides, the effect of the thermal treatment on the dimensional changes of woods was followed by dilatometry.

\section{MATERIALS AND METHODS}

The $E$. nitens trees used for this study were collected from an 8 years old plantation located in the State of Michoacán, Mexico, at $19^{\circ} 54^{\prime} \mathrm{N}$ and $100^{\circ} 27^{\prime} \mathrm{W}$ and at an altitude of $2020 \mathrm{~m}$, with temperatures ranging between 14 and $30^{\circ} \mathrm{C}$ and a mean annual precipitation of $897.7 \mathrm{~mm}$. The $G$. arborea and $T$. grandis trees were collected from a 12 years old plantation located in the State of Michoacán, at $19^{\circ} 12^{\prime} \mathrm{N}$ and $101^{\circ} 53^{\prime} \mathrm{W}$ and at an altitude of $514 \mathrm{~m}$, with warm humid climate with summer rains.

The logs were sawn into boards in a simple band saw (4" wide), then kiln dried, in a Hildebrand $\AA$ wood dryer (capacity of $\mathrm{I} \mathrm{m}^{3}$ ), to a final moisture content of $12 \%$.

Due to the anisotropy of the wood, the measurements were registered in their three main directions: radial, tangential and longitudinal. The longitudinal direction $(L)$ is parallel to the fiber grain; the radial direction $(R)$ is normal to the growth rings (perpendicular to the grain in the radial direction); and the tangential direction $(T)$ is perpendicular to the grain but tangent to the growth rings (Kretschmann, 20l0). These directions are shown in Figure I.

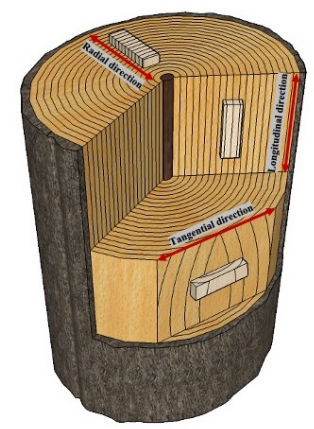

FIGURE I Three principal directions of wood with respect to grain direction and growth rings. 
The samples to evaluate the thermal expansion and the compression strength were specimens of $8 \times 8 \times$ $20 \mathrm{~mm}$, where the largest dimension corresponds to the evaluated direction, Figure. 2.

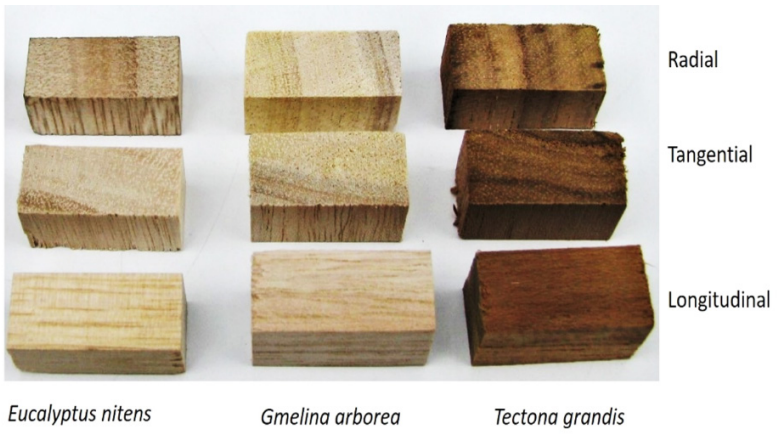

FIGURE 2 Samples of the three different woods in the longitudinal, tangential and radial directions.

The samples were heated at $10^{\circ} \mathrm{C}$ min-I until reaching 140,160 and $180^{\circ} \mathrm{C}$ with a dwell time of I $\mathrm{h}$ at each temperature. The maximum temperature of the heat treatment was determined to be $180^{\circ} \mathrm{C}$ because several authors have found significant reductions in mechanical strength from $190-200^{\circ} \mathrm{C}$ or when prolonged times are applied (Kamdem et al., 2002; Bekhta and Niemz, 2003; Unsal and Ayrilmis, 2005; Esteves et al., 2007; Calonego et al., 20 I2). Dimensional changes during the whole thermal cycle were measured in each one of the wood directions with a vertical dilatometer Linseis L75. After the thermal treatment, the samples were heated up to $100^{\circ} \mathrm{C}$ with a heating rate of $10^{\circ} \mathrm{Cmin}-\mathrm{I}$ in order to estimate the thermal expansion coefficient for the samples without moisture. From the data obtained by dilatometry, the CTEs were estimated by plotting the axial deformation as a function of the temperature and fitting a straight line, which slope corresponds to the CTE. This value was calculated for each wood specimen for both conditions: at moisture content (MC) of $12 \%$ (before thermal treatment) and in dry wood (at $0 \% \mathrm{MC}$ ) after the thermal treatment.

The specimens were weighed before and after thermal treatment with an Ohaus analytical balance with a minimum resolution of $0.01 \mathrm{~g}$. The mass loss of the wood samples was calculated from the data obtained. Then, the samples were subjected to a compression test in triplicate in an Instron I 195/4360 universal testing machine with a maximum load capacity of 10 tons. Test specimens with and without thermal treatment were evaluated in each one of the main directions of the wood. The test was performed at a speed of $5 \mathrm{~mm}$ minI until failure. The modulus of elasticity (MOE) and the stress at proportional limit $(\sigma \mathrm{PL})$ were estimated from the stressstrain curve that is obtained from the load-displacement data provided by the machine. To calculate the stress, the surface area of the sample was corrected by assuming that the volume was constant during compression. This assumption is likely false, but it is reasonable at low strain, in the domain where MOE and $\sigma \mathrm{PL}$ are estimated. The axial strain is calculated as the ratio of the real axial displacement (after machine stiffness correction) to the initial height of samples. The modulus of rupture (MOR) was determined as the maximum stress that was reached for the wood.

\section{RESULTS AND DISCUSSION}

The axial deformation of the samples during the whole thermal cycle is plotted as a function of the time during the whole thermal cycle for the three directions, Fig. 3. At the beginning of each curve, it is observed a dilation which is due to the thermal expansion by reaching a maximum value. Next, a sharp shrinkage is noticed around $80^{\circ} \mathrm{C}$ that is assumed to be caused by the water loss and finished along the $140^{\circ} \mathrm{C}$ plateau. After that, the thermal expansion generates a dilation when the temperature increased up to $160^{\circ} \mathrm{C}$. Along the plateau at this temperature, any dimensional change was detected. Another expansion is detected when the temperature increased up to $180^{\circ} \mathrm{C}$, then it is observed a shrinkage on the $180^{\circ} \mathrm{C}$ plateau, which is assumed to be caused by certain level of wood degradation due to high temperature exposure.

The same behavior was observed for all samples, although it ocurred in the tangential direction the largest deformation followed by the radial direction. The longitudinal direction showed the lowest dimensional change. These trends are similar to those reported by several authors (Kubler et al., 1973; Glass and Zelinka, 2010; Zhao et al., 2016; Kaung and Thanate, 2020) where, the thermal expansion of wood in the radial and the tangential direction is higher than that in the longitudinal one. This is mainly attribued to the cellulose in the wood cell wall (Zhao et al., 2016). (Hori and Wada, 2005) mentionned that the crystalline structure of the wood cellulose dominates the anisotropic thermal expansion in the three directions of wood. On the other hand, (Li et al., 20I2) found that in the longitudinal direction the cellulose chain obtains its maximum amplitude; while the difference between radial and tangential direction depends mainly on the restriction of the wood structure and the cell morphology.

Figure 4 shows the CTE obtained for all samples in both directions, tangential, Fig. 4a, and radial Fig. 4b. The longitudinal direction is not plotted because the axial deformation measured by dilatometry was practically null. It is found that the CTE changes when the direction of the wood does it, and higher values of CTE are 

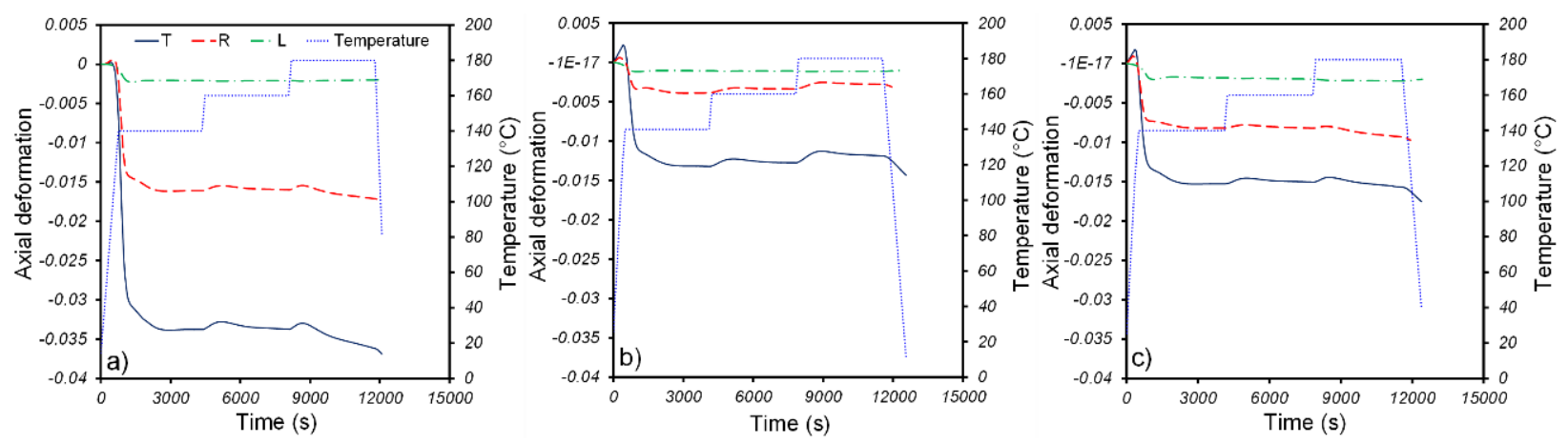

FIGURE 3 Axial deformation as a function of the time along the whole thermal cycle for a) E. nitens, b) T. grandis, c) G. arborea.
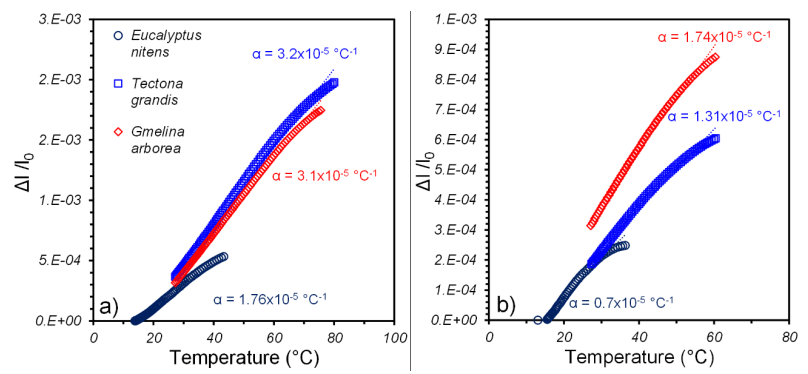

FIGURE 4 Axial deformation as a function of the temperature before thermal treatment (I2\% MC) in two wood directions; a) tangential and b) radial.

measured for the tangential direction. The highest CTE among the woods studied in here was estimated for the T. grandis wood, which resulted to be four times higher than the one for the $E$. nitens in the tangential direction. On the other hand, for the radial direction the $G$. arborea wood shows the highest CTE value. Nevertheless, the values found were close for all the samples, except for the $E$. nitens which presents the lowest one.

The CTE of the woods studied were similar to the values reported by (Kaung and Thanate, 2020) for different woods: Xylia xylocarpa (at 12\% MC, $\alpha_{\mathrm{T}}=$ 5.I, $\alpha R=3.8$; at $0 \% M C, \alpha_{T}=4.1, \alpha_{R}=3.1,10-5{ }^{\circ} \mathrm{C}$ '), Azadirachta excelsa (at 12\% MC, $a_{T}=4.3, a_{R}=$ 3.7; $\left.a_{t} 0 \% M C, a_{T}=3.1, a_{R}=2.3,10-5{ }^{\circ} C^{-1}\right)$, Hevea brasillienisis (at I2\% MC, $\alpha_{T}=4.8, \alpha_{R}=3.8 ; a_{t} 0 \% M C$, $\left.\alpha_{T}=3.7, \alpha_{R}=2.7,10-5^{\circ} \mathrm{C}^{-1}\right)$.

In order to evaluate the degradation of the wood, which is associated with the shrinkage measured at $180^{\circ} \mathrm{C}$ plateau, the deformation rate is plotted as a function of the time during the time that woods remain at $180^{\circ} \mathrm{C}$, Fig. 5 . An increment in the deformation rate is detected at the beginning until a maximum value is reached, then a decrease on the deformation rate is noticed for all woods. It was found that the $E$. nitens wood is more susceptible to be damaged under the thermal treatment, because the deformation rate is almost seven times higher than that obtained for the $T$. grandis wood. The results show a characteristic mass loss at

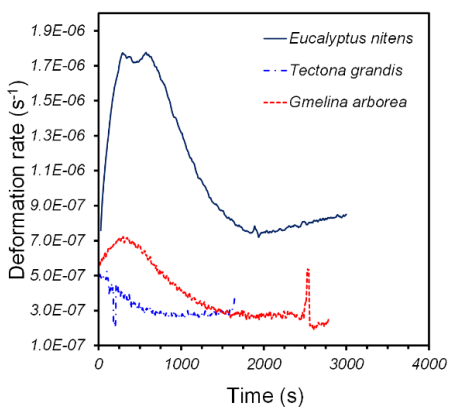

FIGURE 5 Deformation rate as a function of the time during the temperature plateau at $180^{\circ} \mathrm{C}$ for all woods.

$180^{\circ} \mathrm{C}$ mainly caused by hemicellulose thermal degradation (Espinoza and Cloutier, 2009).

Table I sumarizes the values of the initial and final density of the three woods. It can be noticed that the density decreased $4,5.3$ and $7.3 \%$ after the thermal treatment, for $T$. grandis, E. nitens and $G$. arborea, respectively, which is due to the elimination of the moisture and the degradation undergone for each wood. (Mendez and Moya, 2018) reported a decrease in density due to thermal treatment of 12.5 and $6.4 \%$ for $T$. grandis and $G$. arborea, respectively, at $210^{\circ} \mathrm{C}$ for $6 \mathrm{~h}$.

On the other hand, (Garibay, 2015) reported a reduction in density of 10,12 and $19 \%$ at $180^{\circ} \mathrm{C}$ for $1.5,2.5$ y $3.5 \mathrm{~h}$, respectively, for $E$. nitens wood. While, (Calonego et al., 2014) reported a decrese of $6.8 \%$ for Eucalyptus grandis wood due to thermal treatment at $180^{\circ} \mathrm{C}$ for $2.5 \mathrm{~h}$.

The mass loss after the thermal treatment is also listed in Table I, which is higher for the G. arborea wood. The value is almost twice of that measured for the $E$. nitens one. The values are similar to those presented by (Mendez and Moya, 2018), who reported mass loss due to the effect of the thermal treatment $\left(185,190,195\right.$ and $\left.200^{\circ} \mathrm{C}\right)$ from 7 to $14 \%$ in $G$. arborea wood. However, the mass loss values of II to I4\% for T. grandis wood, differ with those of this work, this could be mainly because other authors used thermal treatments at higher temperatures like 205, 210,215 and $220^{\circ} \mathrm{C}$. As it was shown above $180^{\circ} \mathrm{C}$ is the beginning to thermally degrade hemicelluloses that have a 
strong effect on the loss of mass. (Garibay, 20I5) reported mass losses of 4.9. 4.7 and $6 \%$, when thermal treating $E$. nitens wood at $180^{\circ} \mathrm{C}$ for $1.5,2.5$ and 3.5 hours, respectively.

Besides, Table I includes the values of the CTE for $12 \% M C$ and the dry wood. Since the values in the longitudinal direction were close to zero, they were excluded, and only the values for the tangential and radial directions are listed. It was found that the CTE values increased when the wood was dry, that could be associated to shrinkage generated by the elimination of the moisture, which results in a competition between shrinkage and dilation as the temperature increases, as it can be observed in Fig. 3 . This does not agree with (Kaung and Thanate, 2020) who obtained higher CTEs values at $12 \%$ MC than those in dry condition for Xylia xylocarpa, Azadirachta excelsa and Hevea brasillienisis woods. The anisotropy between the three directions was found as reported by other authors (Kubler et al., 1973; Glass and Zelinka, 20I0; Zhao et al., 2016; Kaung and Thanate, 2020). For all samples, the CTE resulted to be approximately two times higher in the tangential direction than in the radial one, value that is also consistent with the difference found in the shrinkage undergone for the samples during the elimination of their moisture.

TABLE I Average values of density $(\rho)$, mass loss and CTE $(\alpha)$ for the three woods. The underscrips are used to indicate; untreated wood (UW), treated wood (TW), tangential direction $(T)$ and radial direction $(R)$.

\begin{tabular}{|c|c|c|c|c|c|c|c|}
\hline & $\rho U W$ & $\rho T W$ & $\begin{array}{c}\text { Mass } \\
\text { loss }\end{array}$ & $\begin{array}{c}\alpha T \\
12 \% \\
M C\end{array}$ & $\begin{array}{c}\alpha R \\
12 \% \\
M C\end{array}$ & $\begin{array}{l}\alpha \mathrm{T} \\
\mathrm{dry}\end{array}$ & $\begin{array}{l}\alpha R \\
\text { dry }\end{array}$ \\
\hline & \multicolumn{2}{|c|}{ g. $\mathrm{cm}^{-3}$} & $\%$ & \multicolumn{4}{|c|}{$10-5^{\circ} \mathrm{C}^{-1}$} \\
\hline$\overline{\text { Euco }}$ & 0.605 & 0.573 & 5.7 & 1.76 & 0.7 & 3 & 2.2 \\
\hline Tect & 0.697 & 0.669 & 7.2 & 3.2 & $|.3|$ & 4.87 & 2.9 \\
\hline Gmelina arborea & 0.522 & 0.484 & 11.9 & 3.1 & 1.74 & 4.85 & 3.2 \\
\hline
\end{tabular}

Figure 6 shows the stress-strain curves in each one of the three main directions, for the three wood species before the thermal treatment. It is observed that the wood in the longitudinal direction supports greater strength, which is five to six times more than in the other two directions, and the strength in the radial direction was slightly greater than that attained by the tangential direction for the $G$. arborea wood. Contrary, the tangential strength was higher than the radial one for the $E$. nitens and $T$. grandis woods.
In order to evaluate the effect of the thermal treatment on the strength of the three woods studied, Fig. 7 shows the stress-strain curves in the three main directions for the three species after the heat treatment. It's found that compressive resistance increases for all woods in the longitudinal direction. The highest values in such direction were those of $E$. nitens and $T$. grandis, this can be attributed to the fact that these are the woods with the highest density, followed by the $G$. arborea. In the radial direction was also found an increment in the compressive resistance, meanwhile, the tangential direction did not show a significative change. This difference could be caused by the elimination of the content of the parenchymal cells from the rays of the wood due to the high temperature effect, which causes an element densification. The increament in resistance to compression of the wood is probably by compaction of wood fibers. Besides, the thermal treatment causes degradation in the hemicelluloses and in the amorphous región of cellulose, thereby, contributing to the increase in the degree of crystallinity of this polymer, occurring a crosslinkage between the lignin and the polymers (Bhuiyan et al., 2000; Bhuiyan et al., 200I; Bekhta and Niemz, 2003; Calonego et al., 2012).

Results of the compression tests, modulus of elasticity, stress at proportional limit, and modulus of rupture are listed in Table 2 . In addition, changes of strength due to thermal treatment effect in each direction of the wood were calculated, which were related to an increment or reduction $(I / R)$ in such properties. It can be seen that there is an increase in strength after thermal treatment. Similarly, a reduction in deformation was found, at least in the longitudinal direction. It was calculated that in the three woods species, the longitudinal direction is the one that undergoes less deformation and supports five to six times more load than in the radial and tangential direction.

When analyzing the modulus of elasticity of the specimens with and without thermal treatment in the longitudinal direction, which was the direction that presented the highest values, the wood of $E$. nitens presented a value
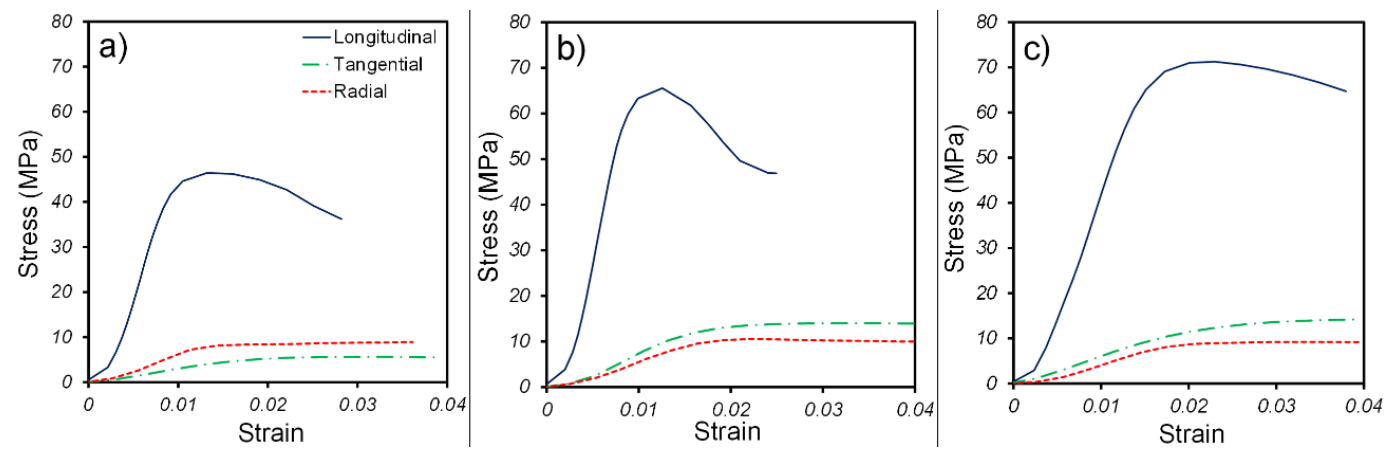

FIGURE 6 Stress-strain plot of three different wood species under simple compression, a) G. arborea, b) E. nitens, and c) T. grandis. 

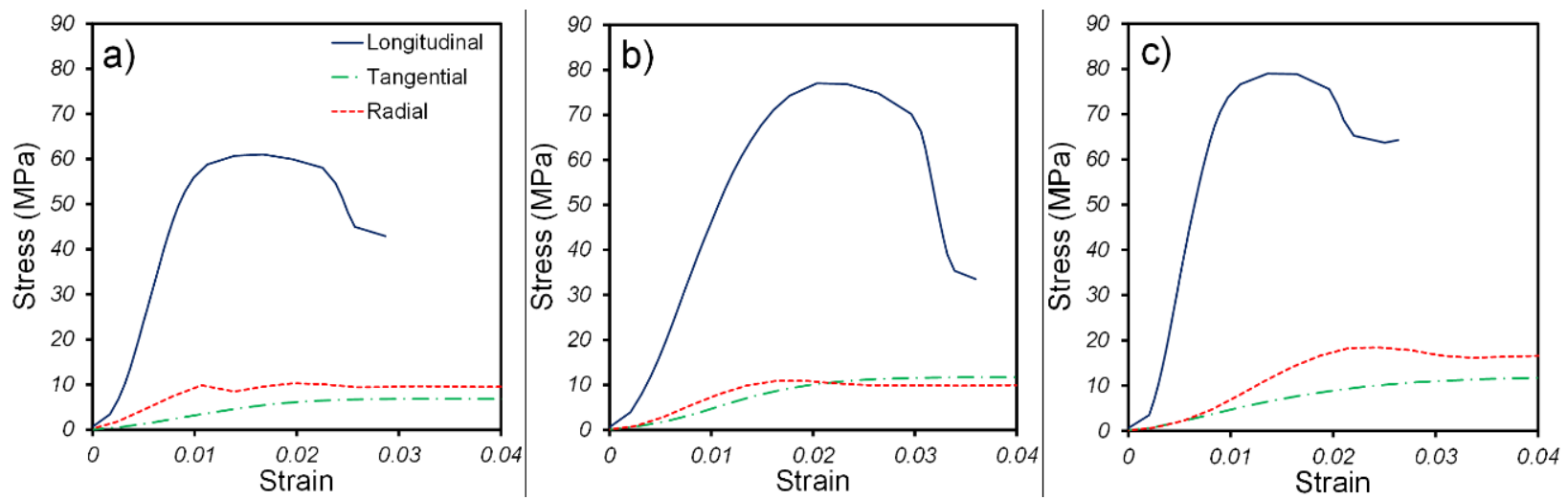

FIGURE 7 Stress-strain plot of three different wood species under simple compression after heat treatment, a) G. arborea, b) $E$. nitens, and c) T. grandis.

of $3.9 \mathrm{GPa}$ without thermal treatment, and $4.4 \mathrm{GPa}$ with thermal treatment, with an increase of $12.8 \%$ due to thermal treatment effect. The $\mathrm{E}$ values are lower to those reported for Eucalyptus urophylla, Eucalyptus grandis growth in commercial plantantions in Brazil by (Ferreira et al., 2019). They concluded that higher $\mathrm{E}$ values are due to the high density of Eucalyptus wood, however, the values of density are similar to the ones measured in this work. Therefore, the differences in $E$ values could be attributed to the anatomical structure in both woods.

The $T$. grandis presented values of MOE of $4.4 \mathrm{GPa}$ without treatment and $5.7 \mathrm{GPa}$ with thermal treatment. These values are similar to those of (Blanco et al., 2014) and (Valero et al., 2005) who reported values for the same kind of species of 6.8 and $4.4 \mathrm{GPa}$, respectively. The T. grandis increased $29.5 \%$ the MOE due to thermal treatment.

The G. arborea presented values of MOE of 4.2 GPa without thermal treatment and $5.5 \mathrm{GPa}$ with thermal treatment. These values were lower than those of (Miranda et al., 20II), which reported a value of $10.6 \mathrm{GPa}$ for the same kind of species without thermal treatment. The $G$. arborea increased MOE by $30.9 \%$ due to thermal treatment

The increment of the MOE due to thermal treatment effect have already been reported by other authors. (Shi et al., 2007; Molinski et al., 2016 and Molinski et al.,2018) reported values from 15 to $30 \%$ higher for thermally treated wood than for the untreated, in Betula spp. and Fraxinus excelsior woods.

The stress at proportional limit in the three directions of the wood is listed in Table 2. It is noticeable that the longitudinal stress was superior to the radial and the tangential. In this longitudinal direction, there was a considerable increase in the stress at proportional limit after the thermal treatment for all the woods, despite the degradation they suffered at high temperature. The increment obtained was different for each one of the woods studied; E. nitens, $15.6 \%$; T. grandis, $15.7 \%$ and $G$. arborea, $26.8 \%$.
The modulus of rupture (MOR) in the three directions of the wood is shown in Table 2. The longitudinal MOR was greater than the radial and the tangential ones. It increased due to thermal treatment: $11.7 \%$ on $E$. nitens, II.9\% on T. grandis and $30.3 \%$ on G. arborea. According to the classification of (Echenique and Plumptre, 1994) for the MOR in longitudinal compression, the wood of $E$. nitens and $G$. arborea are classified as medium resistance for both untreated wood and treated wood. The MOR of $T$. grandis increased from medium to high, due to the effect of thermal treatment. The increment in compressive strength parallel to grain caused by thermal treatments have been reported in the literature, for example, (Calonego et al., 2012) reported increments of $3.7 \%$ when applying thermal treatments at $180^{\circ} \mathrm{C}$ in Eucalyptus grandis wood.

TABLE 2 Mechanical properties under axial compression of three woods. In where (UW) means untreated wood, (TW) means treated wood and (I/R) means Increase or reduction.

\begin{tabular}{|c|c|c|c|c|c|c|c|c|c|}
\hline \multirow[t]{3}{*}{ Direction } & \multicolumn{3}{|c|}{$\begin{array}{l}\text { Modulus of } \\
\text { elasticity } \\
\text { (MOE) }\end{array}$} & \multicolumn{3}{|c|}{$\begin{array}{c}\text { Stress at } \\
\text { proportional limit } \\
(\sigma P L)\end{array}$} & \multicolumn{3}{|c|}{$\begin{array}{l}\text { Modulus of } \\
\text { rupture } \\
\text { (MOR) }\end{array}$} \\
\hline & (UW) & (TW) & $(\mathrm{l} / \mathrm{R})$ & (UW) & (TW) & $(\mathrm{l} / \mathrm{R})$ & (UW) & (TW) & $(\mathrm{l} / \mathrm{R})$ \\
\hline & $\mathrm{GPa}$ & $\mathrm{GPa}$ & $\%$ & $\mathrm{MPa}$ & $\mathrm{MPa}$ & $\%$ & $\mathrm{MPa}$ & $\mathrm{MPa}$ & $\%$ \\
\hline \multicolumn{10}{|c|}{ Eucalyptus nitens } \\
\hline Longitudinal & 3.9 & 4.4 & 12.8 & 51 & 59 & 15.6 & 60.4 & 67.5 & 11.7 \\
\hline Radial & 0.57 & 0.52 & -8.7 & 9.9 & II & II.I & 10.1 & 11.4 & 12 \\
\hline Tangential & 0.53 & 0.54 & 1.8 & 8.9 & 10.9 & 22.4 & 11.3 & 11.8 & 4.4 \\
\hline \multicolumn{10}{|c|}{ Tectona grandis } \\
\hline Longitudinal & 4.4 & 5.7 & 29.5 & 57 & 66 & 15.7 & 67 & 75 & 11.9 \\
\hline Radial & 0.73 & 0.81 & 10.9 & 13 & 15.3 & 17.6 & 13.3 & 15.8 & 18.7 \\
\hline Tangential & 0.47 & 0.39 & -17 & 9.3 & 9.1 & -2.1 & 11.5 & 11.6 & 0.8 \\
\hline \multicolumn{10}{|c|}{ Gmelina arborea } \\
\hline Longitudinal & 4.2 & 5.5 & 30.9 & 4 4I & 52 & 26.8 & 46.4 & 60.5 & 30.3 \\
\hline Radial & 0.58 & 0.86 & 48.2 & 8.1 & 9.5 & 17.2 & 9.1 & 10 & 9.8 \\
\hline Tangential & 0.29 & 0.25 & -13.7 & 5.1 & 5.9 & 15.6 & 5.6 & 6.5 & 16 \\
\hline
\end{tabular}

\section{CONCLUSIONS}

The mass loss after the thermal treatment was higher for the G. arborea wood than for $E$. nitens and T. grandis, due to its lower density.

Dilatometry tests allowed to follow the dimensional changes during the whole thermal treatment, by which indicates the shrinkage induced by moisture elimination 
around $70{ }^{\circ} \mathrm{C}$ as well as the shrinkage obtained by the elimination of hemicelluloses at $180^{\circ} \mathrm{C}$.

It was found anisotropy of the CTE for the three main directions of the wood. The values in the longitudinal direction were close to zero. The values in the tangential direction were higher than in the radial direction.

A high anisotropy of the strength was found for the three main directions of the wood. The highest values of compressive strength ocurred in the longitudinal direction for all woods. The highest values of longitudinal strength ocurred by the woods of T. grandis and $\mathrm{E}$. nitens, which is associated to their higher density.

The thermal treatment increased the strength to compression and the resistance to deformation of the three woods.

\section{ACKNOWLEDGEMENT}

This research was financially supported by the Scientific Research Department $(\mathrm{ClC})$ of the Universidad Michoacana de San Nicolas de Hidalgo.

\section{REFERENCES}

ANANÍAS, R. A.; SEPÚLVEDA-VILLARROEL, V.; PÉREZPEÑA, N.; LEANDRO-ZUÑIGA, L.; SALVO-SEPÚLVEDA, L.; SALINAS-LIRA, C.; ELUSTONDO, D. M. Collapse of Eucalyptus nitens wood after drying depending on the radial location within the stem. Drying Technology, v.32, n.14, p. 1699-1705, 2014.

BEKHTA, P.; NIEMZ, P. Effect of high temperature on the change in color, dimensional stability and mechanical properties of spruce wood. Holzforschung, v.57, p. 539-546, 2003.

BHAT, K. M.; PRIYA, P. B.; RUGMINI, P. Characterisation of juvenile wood in teak. Wood Science and Technology, v. 34, n. 6, p. 5I7-532, 2001.

BHUIYAN, T. R.; HIRAI, N.; SOBUE, N. Changes of crystallinity in wood cellulose by heat treatment under dried and moist conditions. Journal of Wood Science, v. 46, p. 43I-436, 2000.

BHUIYAN, T. R.; HIRAI, N.; SOBUE, N. Effect of intermittent heat treatment on crystallinity in wood cellulose. Journal of Wood Science, v. 47, p. 336-34I, 200 I.

BLANCO-FLOREZ, J.; FERNANDO-TRUGILHO, P.; TARCISIO-LIMA, J.; GHERARDI-HEIN, P. R.; MOREIRA DA SILVA, J. R. Characterization of young wood Tectona grandis L. f. planted in Brazil. Madera y bosques, v. 20, $n$. I, p. II-20, 2014.

CALONEGO, F. W.; SEVERO, E. T. D.; FIGUEIREDO, J. V. Effect of Thermal Modification on the Physical Properties of Juvenile and Mature Woods of Eucalyptus grandis. Floresta e Ambiente, v. 2 I, n. I, p. 108-I I3, 2014.
CALONEGO, F. W.; SEVERO, E. T. D.; BALLARIN, A. W. Physical and mechanical properties of thermally modified wood from E. grandis. European Journal of Wood and Wood Products, v.70, p.453-460, 2012.

ECHENIQUE, R.; PLUMPTRE, R. A. Guía para el uso de Maderas de Belice y México. Universidad de Guadalajara, Consejo Británico, Laboratorio de Ciencia y Tecnología de la Madera, A. C., Universidad de Oxford. Oxford. 1994. 196 p.

ESPINOZA, H. R.; CLOUTIER, A. Thermal degradation and thermal conductivity of gypsum-cement particleboard. Wood Fiber Sci., v. 4I, n. I, p. I3-21, 2009.

ESTEVES, B.; MARQUES, A. V.; DOMINGOS, I.; PEREIRA, H. Influence of steam heating on the properties of pine (Pinus pinaster) and eucalypt (Eucalyptus globulos) wood. Wood Science and Technology, v.4I, p. I93-207, 2007.

ESTEVES, B.; NUNES, L.; DOMINGOS, I.; PEREIRA, $\mathrm{H}$. Comparison Between Heat Treated Sapwood and Heartwood from Pinus pinaster. European Journal of Wood and Wood Products, v.72, p. 53-60, 2014.

EVANS, J. S. O. Negative thermal expansión materials. Journal of the Chemical Society, Dalton Transactions, v. 19, p. 3317-3326, 1999.

FERREIRA, M. D.; RODOLFO DE MELO, R.; TONINI, H.; PIMENTA, A. S.; GATTO, D. A.; BELTRAME, R.; STANGERLIN, D. M. Physical-mechanical properties of wood from a eucalyptus clone planted in an integrated crop-livestock-forest system. International Wood Products Journal, online published, I-8, 2019.

GARIBAY, G. A. Efecto del termotratamiento en las propiedades físico-mecánicas de Eucalyptus nitens (Deane \& Maiden) procedente de una plantación comercial. 2015.73 p. M.C.thesis. Universidad Michoacana de San Nicolás de Hidalgo, México.

GLASS, S. V.; ZELINKA, S. L. Moisture relations and physical properties of wood. In Wood Handbook: Wood as an Engineering Material. USDA Forest Service, Forest Products Laboratory, General Technical Report FPLGTR-190, Madison, WI, 2010. p. 4-I-4-19.

GOLI, G.; BECHERINI, F.; DI TUCCIO, M. C.; BERNARDI, A.; FIORAVANTI, M. Thermal expansion of wood at different equilibrium moisture contents. Journal of wood science. v. 65, n.4, p. I-7, 2019

GONZÁLES, T. G.; SERRANO, M. J. Propiedades y utilizaciones de la madera de melina (Gmelina arborea Roxb) procedente de árboles plantados en Costa Rica. Revista Forestal Mesoamericana Kurú, v. I, n. I, p. 77-86, 2012.

GUNDUZ, G.; AYDEMIR, D. The influence of mass loss on the mechanical properties of heat-treated black pine wood. Wood Research, v. 54, n. 4, p. 33-42, 2009.

HORI, R.; WADA, M. The thermal expansion of wood cellulose crystals. Cellulose, v. I2, n. 5, p. 479-484, 2005. 
IBACH, R. E. Specialty treatments. In: Wood Handbook: Wood as an Engineering Material. USDA Forest Service, Forest Products Laboratory, General Technical Report FPL-GTR-190, Madison, WI. 2010. p. 19-I-19-16

KAMDEM, D. P.; PIZZI, A.; JERMANNAUD, A. Durability of heattreated wood. Holz Roh- Werkst, v. 60, p. I-6, 2002.

KAUNG, M. T.; THANATE, R. Coefficient of thermal expansion of rubberwood (Hevea brasiliensis) in convective drying process. Journal of Tropical Forest Science, v. 32, n. I, p. 72-82, 2020.

KEOGH, R. M. Future of teak and the high-grade tropical hardwood sector: planted forests and trees working paper, Food and Agriculture Organization of the United Nations. Available at: http://www.fao.org/docrep/012/ k6549e/ k6549e00.pdf, Accessed in: July I I th 2019.

KESIK, H. I.; KORKUT, S.; HIZIROGLU, S.; SEVIK, H. An Evaluation of Properties of Four Heat Treated Wood Species. Industrial Crops and Products, v. 60, n. I, p. 60-67, 2014.

KRETSCHMANN, D. E. Mechanical Properties of Wood. In Wood Handbook: Wood as an Engineering Material. USDA Forest Service, Forest Products Laboratory, General Technical Report FPL-GTR-190, Madison, WI. 20I0. p. 5-I-5-46

KUBLER, H.; LIANG, L.; CHANG L. S. Thermal Expansion of Moist Wood. Wood and fiber, v. 5, n. 3, p. 257-267, 1973.

LI, N. P.; LONG, J. B.; SU, L.; WANG, L.; ZHONG, S. Experimental and theoretical study on thermal and moisture characteristics of new-type bamboo structure wall. Journal of Central South University, v. 19, n. 3, p. 600-608, 2012

MENDEZ, M. L. D.; MOYA, R. Effect of thermo-treatment on the physical and mechanical, color, fungal durability of wood of Tectona grandis and Gmelina arborea from forest plantations. Materials Science, v. 24, n. I, p. 59-68, 2018.

MIKI, T.; SUGIMOTO, H.; FURUTA, Y.; SHIGEMATSU, I.; KANAYAMA, K. Anomalous thermal expansion behaviors of wood under dry and low-temperature conditions. Holzforschung, v. 68, n.5, p. 567-574, 2014.

MIRANDA, I.; SOUSA, V.; PEREIRA, H. Wood properties of teak (Tectona grandis) from a mature unmanaged stand in East Timor. Journal of wood science, v.57, n. 3, p. I7I-I78, 201 I.

MOLINSKI, W.; ROSZYK, E.; JABŁOŃSKI, A.; PUSZYŃSKI, J.; CEGIE七A, J. Mechanical parameters of thermally modified ash wood determined on compression in radial direction. Maderas: Ciencia y Tecnología, v. I8, n. 4, p. 577-586, 2016.
MOLINSKI, W.; ROSZYK, E.; JABŁOŃSKI, A.; PUSZYŃSKI, J.; CEGIEŁA, J. Mechanical parameters of thermally modified ash wood determined on compression in tangential direction. Maderas: Ciencia y Tecnología, v. 20, n. 2, p. 267-276, 2018.

MOYA, R. R.; LEANDRO, Z. L. Melina: Gmelina arborea Kunth. Verbenaceae. Ficha técnica 5. In: tecnología de la madera de plantaciones forestales: Fichas técnicas. Revista Forestal Mesoamericana Kuru, v. 7, n. 18-19, p. 87-101, 2010.

OKAJI, M. Absolute thermal expansión measurements of singlecrystal silicon in the range $300-1300 \mathrm{~K}$ with an interferometric dilatometer. International Journal of Thermophysics, v. 9, n. 6, p. II0I-I109, 1988.

PELAEZ, S. M. R.; YADAMA, V.; LOWELL, E.; ESPINOZA, H. R. $A$ review of wood thermal pretreatments to improve wood composite properties. Wood Science and Technology, v. 47, p. $|285-13| 9,2013$.

PIZZO, B.; RIZZO, G.; LAVISCI, P. Comparison of thermal expansion of wood and epoxy adhesives. Holz als Roh und Werkst, v.60, p. 285-290, 2002.

ROBLES, F. V.; ECHENIQUE, M. R. Estructuras de madera, Limusa. 1983. $367 \mathrm{p}$.

SHI, J.; KOCAEFE, D.; ZHANG, J. Mechanical behavior of Quebec wood species heat-treated using thermo wood process. Holz Roh Werkst, v. 65, n. 4, p. 255-259, 2007.

UNSAL, O.; AYRILMIS, N. Variations in compression strength and surface roughness of heat-treated Turkish river red gum (Eucalyptus camaldulensis) wood. Journal of Wood Science, v. 5I, p. 405-409, 2005.

VALERO, S. W.; REYES, E. C.; GARAY, D. A. Study of the physicalmechanical properties of 20 years old Tectona grandis from plantations in the Experimental Unit of the Forest Reserve Ticoporo, Barinas State. La Revista Forestal Venezolana, v. 49, n. I, p. 6I-74, 2005.

ZEISIG, A.; SIEGESMUND, S.; WEISS, T. Thermal expansion and its control on the durability of marbles. Geological Society London Special Publication, v. 205, p. 65-80, 2002.

ZERIOUH, A.; BELKBIR, L. Dilatometry analysis of Moroccan acacia wood under a nitrogen atmosphere. Thermochimica acta, v. 287, n. 2, p. 293-298, 1996.

ZHAO, L.; JIANG, J.; LU, J. Effect of thermal expansion at low temperature on mechanical properties of Birch wood. Cold Region Science and Technology, v. I26, p. 6I-65, 2016. 